\title{
ICT Innovations in Teaching and Learning ( $T$ \& L) At a Private University College
}

Saharia Ismail, Roslida Saad, Noor Adawiyah Ahmad Radzi, Nor Ainee Idris, Noorizda Emellia Mohd Aziz \& Mohd Hisham Mohamad

To Link this Article: http://dx.doi.org/10.6007/IJARBSS/v11-i10/11348

DOI:10.6007/IJARBSS/v11-i10/11348

Received: 03 August 2021, Revised: 26 August 2021, Accepted: 14 September 2021

Published Online: 10 October 2021

In-Text Citation: (Ismail et al., 2021)

To Cite this Article: Ismail, S., Saad, R., Radzi, N. A. A., Idris, N. A., Aziz, N. E. M., \& Mohamad, M. H. (2021). ICT Innovations in Teaching and Learning ( $\mathrm{T} \& \mathrm{~L})$ At a Private University College. International Journal of Academic Research in Business and Social Sciences, 11(10), 540 - 556.

Copyright: (c) 2021 The Author(s)

Published by Human Resource Management Academic Research Society (www.hrmars.com)

This article is published under the Creative Commons Attribution (CC BY 4.0) license. Anyone may reproduce, distribute, translate and create derivative works of this article (for both commercial and non-commercial purposes), subject to full attribution to the original publication and authors. The full terms of this license may be seen at: http://creativecommons.org/licences/by/4.0/legalcode

Vol. 11, No. 10, 2021, Pg. 540 - 556

Full Terms \& Conditions of access and use can be found at http://hrmars.com/index.php/pages/detail/publication-ethics 


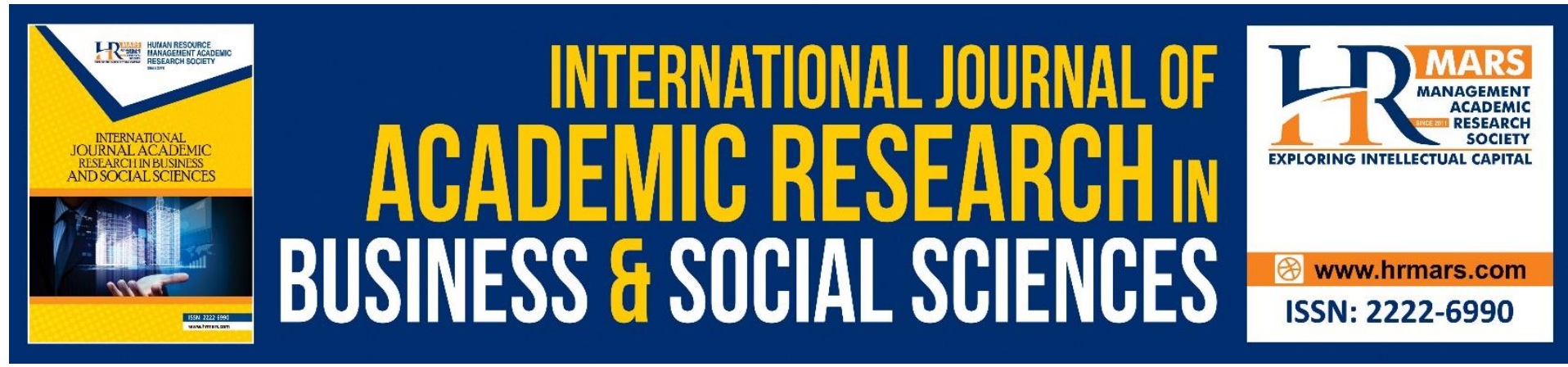

\title{
ICT Innovations in Teaching and Learning ( $T$ \& $L$ ) At a Private University College
}

\author{
${ }^{1}$ Saharia Ismail, ${ }^{2}$ Roslida Saad, ${ }^{3}$ Noor Adawiyah Ahmad Radzi, \\ ${ }^{4}$ Nor Ainee Idris, ${ }^{5}$ Noorizda Emellia Mohd Aziz \& ${ }^{6}$ Mohd Hisham \\ Mohamad \\ 1,2,3,4 Fakulti Bahasa \& Pendidikan, KUIM, ${ }^{5}$ Fakulti Inovasi Perniagaan \& Teknologi, KUIM, \\ ${ }^{6}$ Arab Secondary School Darul Falah Melaka
}

\begin{abstract}
This study aims to identify KUIM lecturers' computer skills, the utilization level of information and communication technology (ICT) innovations in teaching and learning (T\&L), the relationship between the two. This study also examined the perceptions of lecturers on the use of ICT innovations in T\&L. This is a survey-type study involving 132 respondents among KUIM lecturers. The instrument is a set of questionnaires consists of four sections. The data were analyzed using descriptive statistics in order to get the frequency, percentage, mean and standard deviation. Inferential analysis was used to see the relationship between the skills in computer with the utilization of ICT innovations by using Pearson Correlation. The main findings in this study found that the level of computer skills is at a high level with a mean $=3.82$. Meanwhile the use of ICT innovations in teaching is at a moderate level with a mean=2.73. The finding of this study shows that there is a significant relationship between computer skills with the utilization of ICT innovations in lecturers' T\&L but at a low level which is $r=0.287$. Therefore, it is suggested to do various ICT trainings or attended by lecturers so that they can use variety of ICT innovations in T\&L.
\end{abstract}

Keywords: IR 4.0, Computer Skill, ICT Innovations in T\&L

\section{Introduction}

In the era facing with industrial revolution 4.0 (IR 4.0), innovations of ICT is an important issue in the global life of today. The big impact in human life that needs countless efforts from many people in order to enhance the level of using computer and the practice innovation in T\&L particularly among lecturers and students of higher learning institutions (IPT). The skill towards computer is closely related with the use of ICT Innovations in a T\&L that is done thus brings fun and eases lecturers and students. Learning based on technology is increasing and given the main emphasis in contemporary education around the world. Education in Malaysia particularly has practiced the use of technology in T\&L since in the 90s. Chin - Chung Tsai (2017) says that technological increment does not only bring development of learning environment but also brings effect to teachers and students in the concept of teaching and learning. The change that is experienced shows towards our elevation in the way we think. The change creates innovations that gives positive impact in the education system. Not only 
it eases communication between teachers/lecturers and students but also shorten the time in searching information and making it into a more creative and innovative results. Innovations of technology emphasize students to study and research on their own compare to the conventional method.

According to Kamus Dewan fourth Edition, innovation means something new that is being introduced like method, system, practice and others that are new. Sufean (2001) defined innovation as a renewal, modification or improving ideas, things, knowledge and the creation of cultural arts civilization with the objective to fulfil certain tastes or certain marketing. Innovation can also be defined as practicing ideas that are created from a productive process (Yayasan Inovasi Malaysia, 2010). Zakaria (2014) in his master's thesis report defines innovation as a style of variation referring to tendency and individual expertise. Meanwhile, Kamarul (2016) explains the concept of innovation in T\&L referring to the characteristics that an educator should have that intends to fulfill the aspiration of a student by moving students' minds based on the concept that Allah the all-Mighty will bestow one's good intention towards others. In short, based on the definitions of innovation given above, it can be explained that the creation of an innovation in T\&L starts from the initiative of an educator who wants a new change to happen to his students according current era. This means if an educator wants his students to possess knowledge and creative and innovative skill, the educator has to put effort towards the objective with any style and method and different from the existing style. In relation to that, lecturers of higher learning institutions have to play the role as education agents and sharers of information who always use ICT innovation as the tool for T\&L as well as cultivating the creative and innovative culture. Therefore, this study aims to identify computer skill and its relation to the usage of ICT innovation in lecturers' T\&L.

The system of high education in Malaysia is moving towards the high usage of ICT in T\&L until it reaches global level. The quality of teaching and innovation in the teaching method is an important contributor to the excellence of IPT in the effort to educate and develop future generation (PPPM (PT) 2015-2025). Through the $2^{\text {nd }}$ surge of PPPM 2015-2025 (PT) has put the excellence of talent of academic staff as a symbol to the achievement of IPT students. The quality of teaching can be seen through the achievement of learning outcome from a course that is being taught. This is related to the teaching style that is practiced whether it is still conventional or it uses delivery style that is congruent according to current needs. Past teaching that is teacher centered has changed to student centered teaching so it can enhance students' self-development in becoming an innovative high thinker thus shaping students to be independent and able to do self-learning.

\section{Problem Statement}

The ability of a lecturer in applying ICT innovations in teaching delivery depends on his skill of using computer. Weakness and lack of skill towards computer brings to the lack of application on ICT innovations in teaching and learning. So, it makes the learning environment less fun because students' level of learning in this era are more exposed to ICT. In this digital era and globalization, the enhancement of information and communication technology demands that changes be made on the teaching and learning methods (Robiah \& Nor, 2007). The pleasure in teaching and learning will lead towards two-way relations between lecturers and students. So, this will give good impact in delivering knowledge because it helps develop students to be independent and innovative in thinking. Besides that, there are teachers who stated that 
lacking of guidance in ICT complicates them to use ICT in T\&L. Lacking of guidance in state-ofthe-art equipment or high technology is also a burden and problem to teachers who are less skillful in the usage of ICT (Tlakirkodi A/P Vinathan, 2016). Based on a research done by Noh et al (2013) among the studied characteristics that contribute to the use of technology innovation in teaching is the knowledge of using ICT and the exposure of using technology. This continuity has demanded students and teachers to master information technology and using media technology in teaching and learning (Mohd \& Zurinah, 2017).

\section{Research Objectives}

The purpose of this study is to measure computer skill and the utilization of ICT innovations in lecturers' T\&L and its relation between computer skill with the utilization of ICT innovations in T\&L. Specifically, the objectives of this research are:

- To identify the level of computer skill among lecturers.

- To measure the level of utilization of ICT innovations in lecturers' T\&L.

- To study lecturers' perception towards the utilization of ICT innovation in T\&L.

- To determine the relation of computer skill with the utilization of ICT innovations towards lecturers' T\&L.

\section{Industrial Revolution}

The fourth Industrial revolution or IR 4.0 is a term currently for the automation style process and the development in the manufacturing management and chain production. It also includes cyber physical system, internet, cloud computing and cognitive computing. There are four design principles in the Industry 4.0 which are interconnection, information transparency, technical help and decentralization decisions. Education in the IR 4.0 gives opportunity to students to have full flexibility in forming their own path of learning and having the freedom to get close to and achieve objectives (Aggarwal \& Avinash, 2019). According to Lelita, Bono \& Niken (2019), today the world has entered an era where everything can be accessed easily through internet, known as the era of Industrial Revolution 4.0. in this era education industries, particularly Islamic universities, are encouraged to do rebranding activities because Islamic values in curriculum and the learning methods at Islamic universities have positive impact from their users.

Concurrently, Nur et al (2020) emphasized in their study that industry 4.0 is commonly known as organizational transformation that has become in the shape of digital an outcome from state-of-the-art technology that is able to produce latest standard, product, efficiency and achievement for consumers and businesses in order to fulfil the needs of marketing paradigm and new services (Khan and Turowski, 2016). Cyber-physical system (CPS) output is the main vision of industry 4.0 and the use of Internet of Things (IOT), cloud computing, Internet of System (iOS), and Radio Frequency Identification (RFID) (Sony \& Naik, 2019). CPS is the computing unification with physical. The use of loT, iOS enable connection from a machine to another machine without human touch.

Meanwhile, Ahmed et al (2020) said that throughout the century, numerous new technological advancements have created something that is known as the fourth industrial revolution or IR4.0 that influences all industrial sectors. Educational organization holds responsibility to educate and preparing young workers to join work forces have to use this new system and technology in the education processes. This study investigates the 
opportunities and challenges faced by development industries and teaching systems. Furthermore, it mentions several literatures about technology that exists and how it can influence the industrial development and the needed skills for new needed jobs. Finally, this study ends with a framework that is acceptable by teaching developmental organization in ensuring continuous transformation in the development and design industries.

Besides that, Ahmed et al (2020) have given the term IR 4.0 as a revolution that emerges in 2011 as an innovative executing digital technology in the industry. However, Michael Buehler (2018) defines it as the unification of complex machinery and physical devices, with sensors and software network, used to predict, control and plan businesses and better societal outcome.

\section{ICT in T\&L today}

ICT has brought a big change in education particularly in the aspect of T\&L (Rogayah and Mohd, 2016). The development and rapidity of ICT in this globalization era demand educational institutions to make major changes to continue being relevant from the aspect of preparation and human capital development to the nation in achieving the status of developed country (Christina @Nur et al., 2016). ICT has become a necessary in the educational field; therefore, ICT is very important and has to be fully utilized by educators in producing informative society and global thinkers (Mohd, 2016; Khairun et al., 2016).

Computer is one of technological tools used in T\&L. Skills in using computer include basics in computer software such as Microsoft Word, Excel, Power Point and others. The same goes to skill of handling and application in computer. The use of ICT in T\&L has given good effect to students. Many researches were done in using ICT in T\&L have shown positive view. Among the benefits are time saving, teaching is much more intriguing because there is audio visual, easing information searches by using internet searches, producing IT -savvy generations as well as enhancing teachers' skills in technology and so on. ICT helps students mastering proper knowledge and skills that is in line with students' interests. Teachers can sharpen students' talent and potentials and instill the fondness feeling towards knowledge.

For education in the 21st century, the skill to use ICT among teachers is important and is a priority. Efficiency in using ICT tools such as Microsoft Word, Power Point, computer, LCD, internet, devices such as mobile phones and the like can give wide exposure to students and simplify delivery method in classroom (Irfan and Nurullizam, 2011). This is because culture and education trend around the world are now mobilized through ICT. Student generation nowadays is the gadget generation whereby their lives are surrounded by gadget and technology. This is the usual style of education today in line with the explosion of advanced technology. It is undeniable that ICT usage in education has become the main pillar in delivering knowledge and information. This is to ensure the quality of T\&L always at the intended over time and remain relevant. Skillful teachers in using and handling ICT during T\&L process is an important characteristic in the 21-century education in producing informative and global thinkers (Mohd, 2016; Khairun et al., 2016).

The big role of ICT and the usage of software in education also help in adding on knowledge to students when ICT is used during T\&L (Abdul Halim 2008). This is proven by several researches that show how the role of ICT in T\&L helps in adding on knowledge by encouraging students to interact, expanding literacy and developing critical minds (Parker, 2008). In sum, 
it can be said that ICT application in T\&L brings significant changes in the process of learning and very effective (Mohd \& Rosnani 2002; Fauziah, 2006).

According to Khadijah et al. (2014) the use of ICT in T\&L process is very important because it makes the learning environment and experience becoming more fun and more effective thus can enhance students' interest and the quality of teachers' teaching (Sharifah, N.P. \& Kamarul, 2011). Interesting software and state of the art gadgets along with young generations' efficiency using it speeding the process of receiving of students towards the information being delivered besides igniting students' creative minds (Ain, 2014; Norasmahani et al., 2015).

The use of interesting slides along with audio effect and animation and graphic, adding more $T \& L$ experience that is intriguing to students. Coincides with the recommendation by the Ministry of Higher Learning Malaysia (KPTM) outlined "online learning globally" in the Malaysian higher education development plan 2013-2025 it is an effort in enhancing the level of Malaysian education at par with other developed countries in the world. It is clear that education today is focused to the use of ICT. Besides that, T\&L platform through applications Zoom, Google Classroom, Google Meet have become the trend of T\&L of today because of Covid 19 that has spread around the world where the movement control order (MCO) was enforced. So, T\&L session has changed mostly to using technology (Zakaria et al., 2020). Through the platform, teachers share teaching materials with students such as teaching video and notes (Siti \& Muniroh, 2020). Generation Z dan generation Alpha go through interesting learning processes through technology and this needs efficiency among teachers in handling technology using computer and mobile phones.

The use of ICT in T\&L helps saving time in searching for information. The conventional method in gaining information is not efficient nowadays because it needs teachers to move from one place to another such as library or to bookstores and this takes a long time or through newspapers where the information is limited. Through ICT, teachers need to be at a place and equipped with proper gadgets, by using internet and computer, variety of information can be achieved swiftly through Google or Yahoo platforms. Alessi and Trollip 2001 say that T\&L through ICT brings a lot of benefits such as easing students to get information at any time, the management of T\&L materials is easier, faster and smoother for teachers and students. Moreover, the effect of pandemic Covid 19 that happened in 2020, the role of ICT in T\&L has become bigger and more important. With the demanding situation that needs information to be updated every now and then, it can be said that ICT really helps T\&L process and can resume online and runs smoothly.

The use of ICT during T\&L brings about satisfactory learning outcome. According to Syed \& Mohd, 2009) T\&L session will be more effective when teachers explain the subject using Power Point, video and audiovisual tools. ICT is characterized as a communication tool that smoothers delivery of knowledge and gives an interesting learning experience. Thus, learning outcome can be achieved to the maximum as planned. According to Tengku (2015) teachers (Islamic Education) for example, preparing teaching materials, notes using Power Point besides using Microsoft Excel and others. 


\section{Innovations of ICT in Teaching and Learning}

The utilization of ICT innovation in T\&L among teachers is very important in developing a more progressive and innovative society in responding to the IR 4.0 challenges. The utilization of ICT has to be hand in hand with the transformation of time with the elevation of knowledge and skills in order to follow the change of current developments. Therefore, the aspect of knowledge in handling computer is really needed in a teacher in order to move forward and enables them to diversify T\&L sessions more effectively. The change of technology in line with IR 4.0 needs mental and physical preparations in innovating ICT so that T\&L becomes more interesting. A good teacher is the teacher that always diversifies their T\&L activities along with the latest development of technology.

However, according to Hamzah and Noraini (2007), there are many teachers who are not prepared with ICT innovations because of lack of exposure related to information technology and they are still not ready to diversify teaching strategies through technology. They are also not prepared to accept ICT fully although they realize the fact that there are a lot of benefits by using ICT. Besides, teachers are also found to have less interest to make a change because they are already comfortable with the current method and delivery. This is in line with the research findings by Fatimah (2017) that there are still less skilful teachers in using the internet application. There are also teachers who do not have experience in handling live teleconferencing video and chat because of lack of exposure. According to Rosnani \& Mohd (2010), training factor is the contributing factor to the enhancement of technological skills among teachers.

This is in contrast with the research findings by Shah et al (2017) found that teachers are already skilful using the internet applications particularly using email, accessing information and webpages. Rogers (2003) in the opinion that among the factors that lead an individual to easily accept an innovation is because of well suited, similarity of innovation with values, knowledge and skills with the existing and suitable with the need of the individual. In this case, a skilful teacher might have used the application on regular basis in administrative work and the preparation of teaching materials such as preparing exercises, examinations and students' learning notes. However, their skill is still limited with the development of IR 4.0. But it is undeniable there are teachers who are highly skilful in application and handling computer such as the application of word processor (Rosnaini, 2006). This is also mentioned in the research findings by Halimahtun and Nor (2003); Norizan (2003); Syarifah (2011). To sum up, the utilization of ICT innovation for the purpose of T\&L has long been used but the level of its usage needs to be enhanced so it is in line with the development of IR 4.0 and teachers can maximize the advantages of technology for the purpose of $T \& L$ to be more efficient.

\section{Research Theory}

In explaining lecturers' perception towards the use of computer, it is related to the theory that was introduced by Fred (1986) which is about the modeling of users' acceptance towards information system (Technology Acceptance Model - TAM). According to Davis, there are 3 internal factors that influence the acceptance the users towards information system. Those factors such as trustworthiness, attitude and users' purpose. Two individual beliefs are it is beneficial (perceived usefulness - PU) and the perception that it gives ease of use (perceived ease of use - PEOU) is the main influence for the behavior in accepting computer (Fred, 1993). 
In this study, lecturers'perception towards the use of information technology as one of the materials in T\&L relies on the trust of lecturers towards the goodness of the technology itself.

Therefore, in producing a positive perception among lecturers, there should be an emphasis and exposure about the advantages of technology in T\&L particularly, and in daily life generally. Thus, the aspect gives positive impact towards skill and application in enhancing the method and delivery during T\&L. Similarly, in facilitating other academic affairs. The same goes to Diffusion Innovation theory that can be used to accept computer as a necessity nowadays. It is a theory pioneered by Everett M. Rogers. Diffusion is a process where an innovation is connected through certain channels according to time among members of a social system (Rogers, 1983). In short, this theory discusses deeply how a new thing whether it is an idea, or technology, goods or technic develops in various audiences until it is fully accepted and practiced by a society.

The diffusion innovation theory can be used in this study to see the level of usage of ICT innovation in lecturers' T\&L and to see lecturers' attitude towards ICT innovation characteristics. The process of innovation is the decision that starts from the level of acceptance until the level of implementation that have been researched and the influencing factors in decision making have been identified. Those factors include attitudes towards innovation characteristics suggested by Rogers that is the relative benefit of computer, compatibility, uncomplicatedness, testability and computer integrity. The use of computerbased teaching aid tools is seen relevant with behaviorism theory. This theory will analyze visible behavior, measurable, drawn and predicted. The behaviorism theory is better known as learning theory because it shapes the whole behavior, experience and human maintenance particularly students through their learning outcome. The impact from this process has created the concept of "human machine". Among the main theories are the emphasis of elements and small parts that are mechanistic, the role of surrounding in shaping reactions and responses, the importance of training, putting importance of mechanism of learning outcome, the role of ability and learning outcome that is achieved is the result of individual behavior himself (Mohd, 2011).

Lecturers who are guided by the behaviorism theory have the opinion that the reaction of students' behavior is the process of action towards environment and the learning outcome that they received. This means students' positive acceptance towards a subject has close relation with teaching aid materials used by lecturers. On the other hand, lecturers are affected by the use of ICT as the result of the reaction that they obtained from trainings and workshops. Suppiah et. al (2009) has the opinion that the behaviorism is the theory that emphasizes the behavior on an individual. In the T\&L process, teaching aid materials in the form of electronic used by lecturers have interesting multimedia elements such as graphic and animation that stimulate habituation.

Rahil et. al (2009) explained, learning through those elements must be fully controlled by the teaching system developer so the objectives of the process such as guidance, continuous reinforcement training and mentoring are important in ensuring the effectiveness of change of behavior. Thus, based on Rogers' theory (1983) and Davis' theory (1993), attitude and belief are the main factors in accepting computer as a tool moving towards the transformation of education innovation. Positive attitude and belief towards something will 
push an individual to do it. Likewise, the Behaviorism theory that says training, workshops or relevant courses are closely related in determining the change of T\&L method particularly in the use of ICT in T\&L. This is supported by Mohd (2011); Suppiah et. al (2008); Rahil et. al (2009) that say the change of an individual behavior towards the commitment of a task or a responsibility. The diversity of lecturers' tasks itself involves the use of ICT can help the lecturers in enhancing their skills in using ICT in T\&L. it can be considered as a training and stimulation to the lecturers in order more interested in the use of ICT. Therefore, overall, in the effort towards transformation in T\&L method in using ICT the main thing that has to have in every lecturer is positive attitude and belief, interest, knowledge and technological skills.

\section{Methodology}

This study is a survey study using a questionnaire instrument. The distribution of the questionnaire was done by the researchers themselves. This instrument has been modified from the instruments of (Mohd, 2014; Hasnuddin et al., 2015)

Mean scores are made as in Table 1 below:

Table 1: Mean Interpretation

\begin{tabular}{l|l}
\hline Mean score & Interpretation \\
\hline 3.67 to 5.00 & High \\
2.34 to 3.66 & Medium \\
1.00 to 2.33 & Low \\
\hline
\end{tabular}

Source: Ahmad (2002)

The questionnaire is divided into four sections, that is Part A, Part B, Part C and Part D. The details of the explanation for each of these parts are as follows in Table 2:

Table 2: Questions Division

\begin{tabular}{|l|l|l|}
\hline Part A & \multicolumn{2}{|l|}{ Demographic of respondents } \\
\hline Part B & Computer Skills & Likert Scale \\
& & 1 - Very unskilled \\
& & 2 - unskilled \\
& & 3 - less skilled \\
& & 4 - skilled \\
& & 5 - very Proficient \\
\hline Part C & Perceptions of the use of & Likert Scale \\
& ICT innovation in Teaching & 1 - Strongly Disagree \\
& and learning. & 2 - Disagree \\
& & 3 - Neither Agree nor Disagree \\
& & 4 - Agree \\
& & 5 - Strongly Agree \\
\hline Part D & The use of ICT innovation & Likert Scale \\
& in teaching and learning & 1 - Never \\
& & 2 - Unskilled \\
& & 3 - Sometimes \\
& & 4 - Frequent \\
& & 5 - Often \\
\hline
\end{tabular}




\section{Findings}

The findings of the study below will be discussed one after another based on the stated objectives of the study.

The demographic distribution of respondents is based on the following Table 3 using descriptive analysis.

Table 3: Demographic Respondents' Analysis

\begin{tabular}{|c|c|c|}
\hline Demographic & Frequency & Percentage \\
\hline $\begin{array}{l}\text { Gender } \\
\text { Male } \\
\text { Female }\end{array}$ & $\begin{array}{l}38 \\
94\end{array}$ & $\begin{array}{l}28.8 \\
71.2\end{array}$ \\
\hline $\begin{array}{l}\text { Age } \\
20 \text { years }-30 \text { years } \\
30 \text { years }-40 \text { years } \\
40 \text { years }-50 \text { years } \\
50 \text { years and above }\end{array}$ & $\begin{array}{l}22 \\
74 \\
24 \\
12\end{array}$ & $\begin{array}{l}16.7 \\
56.1 \\
18.2 \\
9.1\end{array}$ \\
\hline $\begin{array}{l}\text { Period of service at KUIM } \\
1 \text { year }-5 \text { years } \\
6 \text { years }-10 \text { years } \\
11 \text { years }-15 \text { years } \\
16 \text { years and above }\end{array}$ & $\begin{array}{l}55 \\
55 \\
11 \\
11\end{array}$ & $\begin{array}{l}41.7 \\
41.7 \\
8.3 \\
8.3 \\
\end{array}$ \\
\hline $\begin{array}{l}\text { Teaching experience inside } \\
\text { and outside of KUIM } \\
\text { Less than } 1 \text { year } \\
1-5 \text { years } \\
6-10 \text { years } \\
11-15 \text { years } \\
16 \text { years and above }\end{array}$ & $\begin{array}{l}12 \\
33 \\
54 \\
18 \\
15\end{array}$ & $\begin{array}{l}9.1 \\
25 \\
40.9 \\
13.6 \\
11.4\end{array}$ \\
\hline $\begin{array}{l}\text { ICT training/ workshops/ } \\
\text { courses attended within } 1 \\
\text { year } \\
\text { Never } \\
1-3 \text { times } \\
4-6 \text { times } \\
7 \text { times and above }\end{array}$ & $\begin{array}{l}27 \\
98 \\
6 \\
1\end{array}$ & $\begin{array}{l}20.5 \\
74.2 \\
4.5 \\
0.75\end{array}$ \\
\hline $\begin{array}{l}\text { Internet facilities used while } \\
\text { at KUIM } \\
\text { KUIM WIFI } \\
\text { Open WIFI } \\
\text { Personal data }\end{array}$ & $\begin{array}{l}54 \\
3 \\
75 \\
\end{array}$ & $\begin{array}{l}40.9 \\
2.3 \\
56.8 \\
\end{array}$ \\
\hline $\begin{array}{l}\text { How often do you use } \\
\text { computers for teaching and } \\
\text { learning purposes in a day? } \\
\text { less than } 1 \text { hour } \\
1-2 \text { hours }\end{array}$ & $\begin{array}{l}5 \\
21 \\
\end{array}$ & $\begin{array}{l}3.8 \\
15.9\end{array}$ \\
\hline
\end{tabular}




\begin{tabular}{l|l|l}
\hline $3-4$ hours & 41 & 31.1 \\
$5-6$ hours & 44 & 33.3 \\
7 hours and above & 21 & 15.9 \\
\hline Total & 132 & 100 \\
\hline
\end{tabular}

Overall, the descriptive analysis includes the demographics of the respondents who are lecturers at KUIM with a total number of 132 respondents. Through the gender analysis obtained, 94 respondents (71.2\%) were female and 38 were male (28.8\%). This explains that female respondents are more than male respondents.

While the age of most respondents is between 30 to 40 years old with a total number of 74 respondents (56.1\%). Followed by 24 respondents (18.2\%) aged between 40 to 50 years and below, another 22 respondents (16.7\%) were aged 20 years to 30 years and below and 12 respondents $(9.1 \%)$ were aged 50 years and above. This distribution shows that the majority of KUIM lecturers involved in this study are between 30 to 40 years old and only a few are aged 50 years and above.

In terms of service period at KUIM, both 1 year - 5 years and 6 years - 10 years have represented a total of $41.7 \%$ which is a total of 55 respondents, service period of 11 years 15 years and 16 years and above were also found to be the same percentage of $8.3 \%$ with a total of 11 respondents while $40.9 \%$ of respondents (54 respondents) have 6-10 years of teaching experience either inside or outside of KUIM, 25\% (33 respondents) have 1-5 years of experience, $13.6 \%$ (18 respondents) have $11-15$ years of teaching experience of 16 years and above (15 respondents) and only $9.1 \%$ (12 respondents) have less than one year of teaching experience. This can explain that the most KUIM lecturers involved in this study have served and experienced in teaching for almost 10 years.

Simultaneously, a total of 98 respondents (74.2\%) have attended 1-3 ICT trainings/ workshops/ courses within a year. 6 respondents (4.5\%) attended it 4-6 times a year. Only one respondent $(0.75 \%)$ attended it 7 times and above and 27 respondents (20.5) never attended any training/ workshops/ ICT courses within a year. Based on the findings of the study, this distribution explains that the majority of the lecturers who attend ICT trainings/ workshops/ ICT courses not more than 3 times a year will have an impact on the use of ICT innovations in their T\&L process. Consequently, the awareness of the importance of ICT innovation needs to be enhanced with various initiatives by attending ICT training/ workshops/ courses compulsorily or on their own initiative.

Most of the respondents have used their own personal internet data facilities while at KUIM, which is $56.8 \%$ representing a total of 75 lecturers, 54 respondents (40.9\%) have used KUIM WIFI and only 3 respondents (2.3\%) used open WIFI. This indicates that most respondents use their personal data to meet the teaching needs that require high internet access. However, they still need good internet access to reach at KUIM because almost half of the respondents use KUIM's WIFI facility. 
Finally, is the frequency of computer use for teaching and learning purposes in a day. A total of 44 respondents (33.3\%) has a frequency of use of $5-6$ hours a day, another 41 respondents (31.1\%) have a frequency of use of 3 - 4 hours, and 21 respondents (15.9\%) required frequency of use 1 - 2 hours and only 3.8\% use computer for less than an hour in a day that represent a total of 5 respondents. This shows that the average hours for respondents use computers for T\&L between 3 - 6 hours a day.

Table 4: Level of computer skills, use of ICT innovations and perceptions of the utilization of ICT innovations.

\begin{tabular}{l|l|l|l}
\hline Items & Mean & $\begin{array}{l}\text { Standard } \\
\text { deviation }\end{array}$ & Level \\
\hline Level of computer skills & 3.82 & .60302 & High \\
The use of ICT Innovation & 2.73 & .71899 & Medium \\
Perceptions of the utilization of ICT & 3.97 & .62930 & High \\
innovations. & & & \\
\hline
\end{tabular}

Table 4 refers to the level of computer skills and the utilization of ICT innovations among KUIM lecturers. In this study, computer skills refer to the basic operation of computers, applications and the use of computers that are common for teaching and learning purposes among KUIM lecturers. The mean overall level of computer skills among KUIM lecturers is at a high level of 3.82. The highest mean was the Microsoft Word application item (mean: 4.26) followed by the Microsoft Power Point application (mean: 4.14). This is probably because this application is the most basic application in the use of computer for T\&L purposes. While the lowest mean is Microsoft Publishers application (mean: 2.90). It is likely that Microsoft Publishers application is only used in a certain area and are more utilized for management purposes. Therefore, it is proposed that more computer skills courses and exposure to various ICT applications be implemented to increase the percentage of lecturers who are highly skilled and proficient in their computer skills.

Whereas the level of use of ICT innovations studied involves appropriate technology applications used for T\&L purposes. The overall mean of the use of ICT innovation in the teaching and learning purposes is at a moderate level of 2.73. The highest mean was Schoology application (4.6) followed by email (4.46), zoom (4.02) and Whats App (3.98). While the lowest items are stream yard (1.45), e-learning (1.55) and loom (1.62). Therefore trainings/ seminars/ workshops with various contents on T\&L purposes should be implemented to increase awareness and level of use of ICT innovations in teaching and learning among KUIM lecturers. At the same time, the cause of the low level in using ICT innovations in T\&L needs to be known through other studies.

Furthermore, the findings related to the perception of lecturers on the use of ICT innovation in T\&L among KUIM lecturers have shown that KUIM lecturers have a positive view on the use of ICT innovations in T\&L. The overall mean is at a high level of 3.97. The highest item is "ICT innovation can help in diversifying activities in teaching and learning" (mean: 4.49). Followed by the item "the use of ICT innovations in teaching and learning is appropriate as a new approach" (mean: 4.29). This means that KUIM lecturers accept that technology is a tool that needs to be used as best as possible to keep pace with the needs of times. Thus, exposure to 
the importance of the use of ICT innovation in T\&L needs to be enhanced among KUIM lecturers to transform T\&L in the 21 century which is now undergoing a transition towards IR5.0. At the same time, it is proposed that in the future research on the use of ICT innovations in T\&L in terms of students' perception should be made to motivate lecturers to change their teaching and learning sessions in line with the needs of the young generation in this age of technology.

\section{The Relationship between Computer Skills and the Utilization of ICT Innovations in Teaching and Learning.}

Table 5: The relationship between computer skills and utilization of ICT innovations

\begin{tabular}{l|l|l}
\hline Variables & $\mathrm{r}$ & $\mathrm{P}$ \\
\hline $\begin{array}{l}\text { Computer skills* } \\
\text { Level of use of } \\
\text { ICT in teaching } \\
\text { and learning }\end{array}$ & $.287^{* *}$ & .001 \\
& & \\
\hline
\end{tabular}

Table 5 shows that there is a significant relationship between computer skills with the utilization of innovations in T\&L of lecturers $(r=0.287, P=0.001<0.01)$ even at a low level. These findings can explain that the higher level of computer skills for the higher use of ICT innovation. This shows that the utilization of ICT innovations is closely related to an individual's computer skills.

\section{Discussions}

The findings show that the level of computer skills among lecturers is at a high level. These findings are appropriate in an era of globalization challenges and the explosion of ICT technology has made the development of education highly emphasized for teachers to be able to master this information technology in R\&D (Robiah \& Nor, 2007). These findings are also in line with the study conducted by Noraini et al (2013) that among the features studied contribute to the use of technological innovation in teaching is knowledge of the use of ICT and exposure to the use of technology.

While, the findings of the study on the utilization of ICT innovation in teaching among lecturers are at a moderate level. Therefore, this situation needs to be addressed because Ahmed et al (2020) say that, throughout this century, many new technological advances were created and something began to be knowns as the fourth industrial revolution or IR4.0. These developments have affected all sectors of the industry. In addition, the study of Abdul, H. et. al (2016) stated that the use of online web technology media has an impact on T\&L and students' performance. This is because the application of internet-based web technology is able to support T\&L in public universities and the implementation of a more effective national education system.

The findings of the study from the aspect of lecturers' perception showed that more than half of the lecturers agreed with the need for ICT in their teaching process. These findings are consistent with the study of Lelita et. al (2019), stated that the world is now in the era of 
industrial revolution 4.0 where most of it is easily accessible through internet access. This argument is supported by Abu \& Zaidah (2017), explaining that structure such an online community can further enhance the effectiveness of the online software used in e-learning.

These findings indicate that there is a significant relationship between computer skills with the utilization of ICT innovations in the T\&L of lecturers but at a low level. This is in line with the study of Mohammad, R. et. al (2016) who stated that an individual's knowledge of the use of ICT innovations is dependent on the level of individual's computer skills which is improved for the spreading of useful knowledge as well as competing for the certain purposes. According to Rogayah and Mohd (2016), ICT has brought about a major change in the field of education especially in the aspects of T\&L.

\section{Recommendation and Conclusion Recommendation}

Limitation of this study for further research needs to be reorganized in population to diversify in sample size. So, a larger population will give more alternatives to the study in depth for different findings. The results will give more impact to encourage ICT innovation among lecturers in Malaysia in order to upgrade teaching and learning skills through technology advancement in this digital era.

\section{Conclusion}

In brief, as an educational organization should be responsible for educating and preparing skilled manpower according to the circulation of world technological process. Not only young people need to prepare themselves with the current technological advances, but also the entire workforce must deepen this new knowledge and technology. So that they can be practised in the educational process. In this era, educational institutions such as Islamic universities are encouraged to rebranding activities because of the Islamic values contained in the curriculum not be outdated. In conclusion, ICT innovation can help the development of education to keep pace with the times. This study contributes to the acceptance of ICT innovations in teaching and learning today.

\section{Acknowledgement}

This research is not under specific grant from any funding agency in the public, commercial or not for profit sectors.

\section{Corresponding Author}

Saharia Ismail

Kolej Universiti Islam Melaka Batu 28, Kuala Sungai Baru, 78200 Melaka, Malaysia.

Email: saharia@kuim.edu.my

\section{References}

Abu, B. Z., \& Zaidah, M. (2017). Pelaksanaan e-pembelajaran dalam proses pengajaran dan pelajaran pensyarah di Politeknik Hulu Terengganu.e-Proceeding National and Invention Competition through Exibition.

Abdul, H. M. D., Lee, S. T., Mohan, P., \& Jamilah, D. (2016). Penerimaan Alat Web 2.0 dalam Pelaksanaan Kurikulum Program Berasaskan Pembelajaran Abad Ke-21 di Institut Pendidikan Guru. Jurnal Penyelidikan Dedikasi Jilid 10, 2016. 
Abdul, H. M. (2008). Hubung kait kemahiran penggunaan komputer perisian ke atas pencapaian matematik kanak-kanak prasekolah. Proceedings International Conference on the Education of Diverse Learners (ICELD 2008). Universiti Kebangsaan Malaysia Bangi.

Abd, S., Noorazman, Nizamuddin, R., Wan, M. R. W. A., Fatimah, J., Affero, I., Erfy, I., \& Hairuddin, H. (2018). Penggunaan Instruksional Teknologi Maklumat Dan Komunikasi (Tmk) Terhadap Mata Pelajaran Teras. Online Journal for TVET Practitioners 3 (2).https://publisher.uthm.edu.my/ojs/index.php/oj-tp/article/view/4838.

Aggarwal, K. K., \& Avinash C. S. (2019). "Higher Education Ecosystem's Preparedness for IR 4.0: An Indian Perspective". National Security, Vivekananda International Foundation Vol.II (2) ISSN 2581-9658 pp. 205-229.

Ahmed, M. S., Kumar, M., \& Mohammed, F. M. (2020). Paradigm Architectural Education for the IR 4.0 Era. https://www.researchgate.net/publication/343809797.

Ain, Z. M. Z. (2014). Penggunaan Bahan Tiga Dimensi (3D) Untuk Meningkatkan Kemahiran Berfikir Aras Tinggi dalam Subjek Kajian Tempatan Bagi Murid Tahun 5. Prosiding Seminar Penyelidikan Tindakan Pelajar.

Asnuurien, Munirah, M., \&, Siti, N. H. (2020). Penggunaan Ict Dalam Pengajaran Dan Pembelajaran; Satu Kajian Di Jabatan Pengajian Am, Politeknik Merlimau Melaka. Retrieved http://www.academia.edu.

Alessi \& Trolip. (2001). Multimedia for learning. 3rd ed. USA: Pearson Education.

Fauziah, A. (2006). Teaching method used in the teaching of the literature component in secondary schools. PhD Thesis. Fakulti Pendidikan, UKM.

Halimatun, S., \& Nor, A. (2003). Pertimbangan Sosial Teknikal Dalam Reka Bentuk Dan Implementasi ICT. Kuala Lumpur: Persatuan Teknologi Pendidikan.

Dan Noraini, H. (2007). Tahap Kesediaan Guru Sains Dalam Penggunaan Teknologi Maklumat Berasakan Komputer Dalam Proses Pengajaran Dan Pembelajaran, Jurnal Teknologi pg 45-60, UTM: Selangor Darul Ehsan.

Hasnuddin, A. R., Norfaizuryana, Z., dan Nor, A. A. K. (2015). Keberkesanan Pengunaan ICT di dalam Pengajaran dan Pembelajaran Pendidikan Islam bagi Sekolah Kebangsaan Desa Pandan Kuala Lumpur. Proceeding of IC-ITS 2015 e-ISBN: 978-967-0850-07-8 International Conference on Information Technology \& Society.

Irfan, N. U., \& Nurullizam, J. (2011). Pola Penyelidikan ICT Dalam Pendidikan Guru Di Malaysia: Analisis Prosiding Teknologi Pendidikan (Trends of ICT Research In Teacher Education: An Analysis of The Malaysian Instructional. Asia Pacific Journal of Educators and Education, 26(1), 1-14.

Khadijah, A. R., Tengku, N. T. O., Mohd, I. H., \& Hafizhah, Z. (2014). Information and Communication Technology among Excellent Islamic Education Teachers in Selangor Malaysia. Journal International Education Studies. Vol. 7, No. 13; 2014, hlm 146-156.

Khan, A., \& Turowski, K. (2016a). A Preliminary Study on Industry 4.0. Journal of Industrial and Intelligent Information, 4(3), 230-234. Https://doi.org/10.18178/jiii.4.3.230-234.

Khan, A., \& Turowski, K. (2016b). A Survey of Current Challenges in Manufacturing Industry and Preparation for Industry 4.0. Advances in Intelligent Systems and Computing, 451, 15-26.https://doi.org/10.1007/978-3-319-33609-1.

Lelita, A. R., Bono, S., \& Niken, P. (2019). Identity Branding for Islamic University in IR 4.0 Era. Advances in Social Science, Education and Humanities Research, volume 339. Atlantis Press. 
Michael, B., Santiago, C., \& Pierre, P. B. (2018). The Fourth Industrial Revolution is about to hit the construction industry. Here's how it can thrive.World Economic Forum. https://weforum.org/agenda/2018/06/constructionindustry-future-scenarios-labourtechnology/. Retrieved in 28/9/2020.

Mohd, A. H. I., \& Rosnaini, M. (2002). Teknik video dalam pengajaran dan pembelajaran: Penggunaan bahan sumber video secara kreatif. Jurnal Bahagian Teknologi Pendidikan 84-91.

Mohd, H. M. (2014). Tahap Penggunaan Komputer Dalam Pengajaran dan Pembelajaran Kalangan Guru Pendidikan Islam di Sekolah Menengah Daerah Alor Gajah Melaka. Master's Dissertation Universiti Kebangsaan Malaysia

Mohammad, R., Emma \& Mohd, Y. (2016). Pengaruh Literasi Kesihatan Terhadap Tingkah Laku Pencarian Maklumat Kesihatan Dalam Kalangan Pelajar Universiti Awam. Jurnal Komunikasi Malaysian Journal of Communication Jilid 32 (2) 2016: 405-424.

Nur, F. H., Sabrinah, A., Beni, W. Y. K. (2020). Accessing Employees' Readiness To Adopt Industry Revolution 4.0 (Ir 4.0). International Journal of Innovation and Industrial Revolution (IJIREV) Volume 2 Issue 3 (June 2020) PP. 15-28. DOI 10.35631/IJIREV.23002. elSSN: 2637-0972.

Norizan, A. R. (2003). Computer Competency of In-Service ESL Teachers In Malaysian Secondary Schools. Doctoral Dissertation. Universiti Kebangsaan Malaysia.

Norizan, A. R., \& Salleh, H. A. R. (1997). Pengajaran Bahasa Berbantukan Komputer: Satu Tinjauan Terhadap Kesediaan Guru-Guru Dan Sekolah-Sekolah Menengah Di Malaysia. Laporan Akhir Penyelidikan UKM.

Parker, L. L. (2008). Technology-mediated learning environments for young English language learners: connections in and out of schools. New York: Lawrence Erlbaum Associates.

Rogers, E. M. (2003). Diffusion of Innovations, 5th edition. New York: Free Press.

Rosnaini, M. (2006). Secondary School Teacher's Basic ICT Readiness. Doctoral Dissertation. Universiti Kebangsaan Malaysia.

Rosnaini \& Mohd, A. (2010), Impact of Training and Experience in Using ICT in-Service Teachers' Basic ICT Literacy, Malaysian Journal of Educational Technology. Volume 10, Number 2, Universiti Kebangsaan Malaysia.

Siti, B. M., \& Muniroh, H. (2020). Pengajaran Dan Pembelajaran Dalam Talian Semasa Perintah Kawalan Pergerakan. SIG: e-Learning@CSeISBN: 978-967-0841-88-5 Publication Date: 11 September 2020.

Shah, R. Z., Mohd, I. H., \& Khadijah, A. R. (2017). Penggunaan ICT dalam Pengajaran dan Pembelajaran Pensyarah Pendidikan Islam di Politeknik Zon Selatan. Tinta Artikulasi Membina Ummah (TAMU) Volume 3 (1), 2017 pg 29-41 e-ISSN: 2289-960X.

Sharifah, N. P., \& Kamarul, A. A. S. (2011). Tahap Kesediaan Penggunaan ICT dalam Pengajaran dan Kesannya Terhadap Hasil Kerja dan Tingkah Laku Murid Prasekolah (Level of Readiness in Using ICT for Teaching and Its Effect on the Work and Behaviour of Preschool Pupils). Jurnal Pendidikan Malaysia 36(1)(2011): 25-34.

Sony, M., \& Naik, S. (2019). Key ingredients for evaluating Industry 4.0 readiness for organizations: a literature review. Benchmarking, (January). https://doi.org/10.1108/BIJ-09-2018-0284.

Syed, M. D. A. I., \& Mohd, L. S. (2009). Peranan ICT Dalam Penyebaran Dakwah Dalam Era Globalisasi. Prosiding Seminar Kebangsaan Dakwah Islamiah di IPT dan Komuniti 2009, hlm 1-25. 
Syuhada, M. S., \& Mohd, A. C. N. (2016). Pembudayaan Penggunaan Teknologi Dalam Pengajaran Dan Pembelajaran Pendidikan Islam. Prosiding wacana Pendidikan Islam Siri Ke 11(WPI11), HIm 191-201.

Tengku, N. T. O. (2015). Teknologi Maklumat dan Komunikasi (TMK) dalam Pengajaran Dan Pembelajaran Guru Cemerlang Pendidikan Islam Di Negeri Selangor. Tesis Sarjana. Universiti Kebangsaan Malaysia.

Zakaria, S., Baskaran, S., Malar, M., Abdul, M. Y., Chin, S. F., Othayakumaran, K. (2020). Kesediaan Penggunaan Google Meet Sebagai Platform Pengajaran Dan Pembelajaran Dalam Talian Bagi Siswa Guru Di Institut Pendidikan Guru Kampus Sultan Abdul Halim. Proceedings of International Conference on the Future of Education IConFEd) 2020, Institute of Teacher Education Tuanku Bainun Campus, Penang, Malaysia, 17-18 November 2020. 